\title{
An Overview of Wind Resource Assessments With Special Reference to The Emirate of Ajman, UAE
}

\author{
Kais Muhammed Fasel, Abdul Salam K. Darwish ${ }^{*}$ (D), Peter Farrell(1), and Hussein Kazem (D) \\ University of Bolton, Bolton, UK
}

Received: 28 June 2021 / Received in final form: 8 September 2021 / Accepted: 8 September 2021

\begin{abstract}
The continuous increase in clean energy demand and reduced $\mathrm{CO}_{2}$ emissions in the UAE and specifically the Emirate of Ajman has put an extreme challenge to the Government. Ajman is one of the seven emirates constituting the United Arab Emirates (UAE). Ajman is located along the Arabian Gulf on its West and bordered by the Emirate of Sharjah on its North, South, and East. The government is taking huge steps in including sustainability principles and clean energy in all of its developments. Successful implementation of green architecture law decree No 10 of 2018 effectively is a sign of such an initiative. Renewable energy sources in this country have had two folds of interest in solar and wind. Recent research works supported the feasibility of using wind energy as an alternative clean source of energy. Site-specific and accurate wind speed information is the first step in the process of bankable wind potential and wind Atlas. This study has compared how wind speed and its distribution varies for similar offshore and onshore locations between two different mesoscale data sources. Also, discussed the main environmental characteristics of Ajman that would influence the implementation of a major wind energy project. In addition, the study made a brief critical overview of the major studies undertaken in the Middle East and North Africa (MENA) region on wind resource assessment. Finally, based on the results, the study makes conclusions, recommendations and a way forward for a bankable wind resources assessment in the Emirate of Ajman. This paper would alert the wind energy industry about the consequence of not considering the best error corrected site specific suitable wind resource data along with other environmental characteristics. The study results show that for offshore, there is $2.9 \mathrm{~m} / \mathrm{s}$ and for Onshore $4.9 \mathrm{~m} / \mathrm{s}$ variations in wind speed at the same location between ECMWF Reanalysis (ERA-5) and NASA Satellite data. Hence It is concluded that error corrected site-specific wind resource assessment is mandatory for assessing the available bankable wind potential since there are considerable variations in wind speed distributions between mesoscale data sets for similar locations. The study also identifies that the Emirate of Ajman has limited space for onshore wind farms; hence the offshore site seems to have good potential that can be utilised for energy generation. However, individual wind turbines can be installed for exploiting the available site-specific onshore wind energy. Finally, the study recommends a way forward for a comprehensive wind resource assessment to help the Emirate of Ajman form a sustainable wind power generation policy.
\end{abstract}

\section{Introduction and background}

Wind Resource Assessment (WRA) calculates how much energy is possible to extract from the wind blowing at a location using a wind turbine. The results help generate a wind atlas for the area showing the distribution of wind energy at various locations for wind energy device installations. WRA involves assessing and quantifying wind resources to calculate average wind speed, average wind energy density, and the average annual energy

\footnotetext{
* e-mail: a.darwish@bolton.ac.uk
}

production (AEP) for a proposed wind power plant. In any location for designing a wind energy system, it is required to have site-specific knowledge of wind resources. Basically, a $5 \%$ error in wind data measurements can lead to $10 \%$ inaccuracy in AEP, which would cause $\pm 10 \%$ inaccuracy in revenue. Finally, this error can be the difference between a financially feasible and a non-feasible wind project [1].

Since wind is a weather phenomenon, there is inherent uncertainty in its long term predictions, especially over the lifetime of a wind farm as a year to year variation in wind speed is influenced by climate indices like El Niño, La Niña, and a variety of other long-term cyclical phenomena. Extrapolation of wind data to the lifetime of a wind farm 
requires assumptions and the use of statistical models. Wind flow models are used in predicting the wind speed at hub heights. These models are solved through various simplifications and assumptions. And these assumptions create ambiguity in assessments of average wind speed at hub height and average AEP. This causes a reduction in revenue and fails to meet the cost of maintenance and operations. Therefore regardless of the size of the wind project, it is a must to conduct accurate WRA. The nonavailability of accurate wind data at various hub heights is a serious issue in the wind industry. This causes to increase in the cost of wind projects. Due to conflicts of interests, there is no sharing of wind resource data between developers. Like rainfall, the wind is also a cyclical phenomenon; hence, a short-term one-year data measurement is risky for predicting wind energy production for 20 years in the future. Hence, a wind project without a highquality long-term wind resource assessment is tough to consider as bankable wind resources and lacks the chance to get funded. Funding agencies require a project to have wind speed data of 3 to 5 years [1]. Even though the government of Ajman already laid its foundation for developing sustainable energy systems in the Emirate through the successful implementation of green architecture law decree No 10 of 2018 , the literature review shows a considerable gap and no WRA study. This mandates a comprehensive WRA over the Emirate to understand the wind resources available either onshore or offshore to utilise the wind resources and to produce the power required to meet the growing demand of the Emirate.

According to the latest census data available, the population of Ajman counts approximately 230,000 inhabitants. Ajman city combines both the inveterate heritage that extends through many years of Emirate history and the magnificent present that builds its renaissance in the persuasion of achieving the highest level of development and progress. And the Emirate's authority has made complete implementation strategies to the United Nations Sustainable Development Goals (UNSDGs) and appointed each SDG to the related activity [2]. Hence finding out suitable locations and identifying the type of wind energy harnessing system(s) that can be utilised for optimum power exploitation from the available wind resource in the Emirate is crucial. Especially considering the scarcity of accessible land, characteristics of the terrain, sensitivity of the receptors and the social impacts. This, in turn, mandates a site-specific validated wind resource assessment.

Wind power projects are often delayed or discarded due to technical weakness in measurement instruments and data management. Moreover, the wind characteristics, especially over Ajman, may depend on and influence by the various climatic factors, extreme events taking place elsewhere in UAE. As stated by [3], we must not be satisified until we have all our energy produced using renewable energy. Referring to the monthly wind data [4] has concluded the opportunity for using different wind energy technology in the Emirate of Ajman by reviewing possible technologies like seawater desalination, street lighting, and buildings integration for lighting purposes. Most importantly, pointed out that desalination techniques using Offshore wind energy are the most applicable technology to the Emirate of Ajman, and concludes that the available wind resource is expected to contribute $20 \%$ of the electricity need Emirate.

The literature review shows that previous researchers used long-term predicted winds obtained from global reanalysis models as a reliable data source for WRA [1]. They claimed that this data is sufficient when the measured or satellite observations are sparse in a specific region. Furthermore, several previous researchers like [5-10] used CFSR, MERRA-2, ECMWF and ERA products such as ERA 40, ERA-Interim, and ERA5 for WRA. Also, as stated by [11], ERA 5 wind data is highly used for wind energy assessments.

This study identifies the gaps and ambiguity in the process of WRA in the light of the prior studies and by analysing the Wind data from a mesoscale model and satellite data. The study results have been utilised to recommend developing an error correction methodology for the WRA over the Emirate of Ajman.

\subsection{Aim}

In the light of identified gaps in the previous studies mentioned in Section 1, this initial investigative study would investigate the variations in wind speed distribution at the same selected onshore and offshore location in the Emirate of Ajman between global reanalysis ERA-5 and NASA Power data. The study would analyse aforementioned data sets to identify the variations in wind speed distributions in light of other environmental parameters in Ajman. Finally, the study aims to recommend a way forward to determine the formation of a methodology for the future site-specific comprehensive WRA studies using measured and a selected global reanalysis wind and weather data sets over the Emirate of Ajman.

The next part of this paper will proceed in the following order:

- Section 2 will discuss the details of the study area.

- Section 3 will discuss the details of the data and methodology adopted for this study.

- Section 4 will discuss the significant studies on Wind Resource Assessments in the MENA region.

- Section 5 will discuss some of the leading environmental characteristics of the Emirate of Ajman, which would influence the implementation of a major wind energy project.

- Section 6 will detail how wind speed varies for an Offshore and Onshore location in Ajman between two different wind data sources.

- Section 7 will discuss the conclusion, way forward and recommendations for a Bankable wind resource assessment in the Emirate of Ajman.

\section{Study area}

\subsection{The Emirate of Ajman}

The Emirate of Ajman lies between the emirates of Sharjah and Um Al-Quwain at The Arabian Gulf with a length of $26 \mathrm{~km}$. It is the smallest among the emirates and has an area 


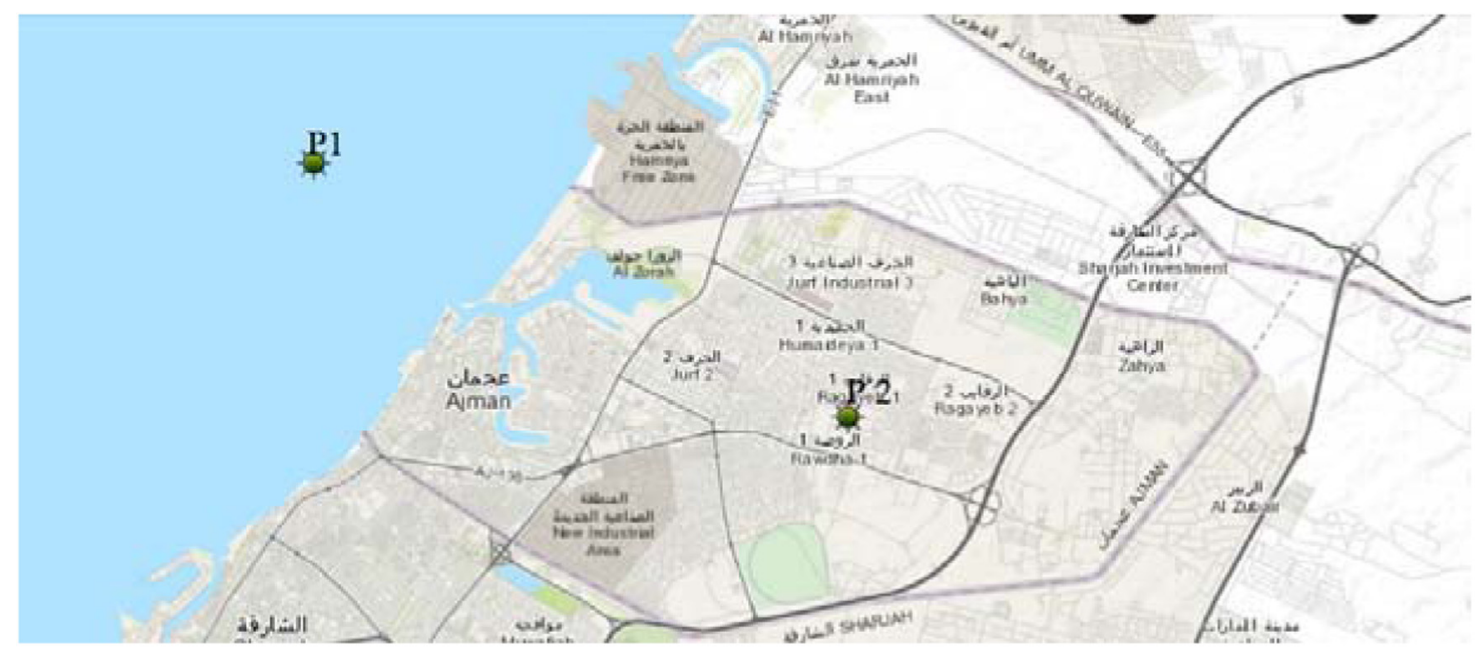

Fig. 1. Overview map of the city of the Emirate of Ajman.

of $460 \mathrm{sq} . \mathrm{km}$. Thus this area is equal to $0.33 \%$ of the total area of the United The Arab Emirates. The Emirate is made up of three far different regions in terms of the topography and the extent of weather, and the regions are: Ajman City, Musfoot and Al-Manama area. The Emirate climate is characterised by moderation, where the temperature is moderate. Humidity is high during the summer, whereas the temperature reaches $25^{\circ} \mathrm{C}$ in winter. Musfoot Area is about $110 \mathrm{~km}$ from the city of Ajmanto the southeast. The area is famous for its fascinating nature that includes the high mountains, such as (Dafta, Madeerah, the White Mountain, Leshan, and AbuFaraj Mountain) also there are valleys such as (Ghalfa, Leshan, Al-Sawamir, Al-Khanfarih, Al-Dafdi(frog) and leem valley). The area is famous for agriculture due to its fertile soil, vast valleys and moderate climate, making the area an adequate centre for tourism and sightseeing. AlManama area is located in a plain full of pebbles and sands. The site is characterised by its fascinating nature, including the mountains such as Al-Ashqar and Bin Elwah Mountain. There are some valleys such as Munsit, Al-Safsaf and Baee Al-Nakheel valley. The area is also famous of agricultural crops. Al-Manama Area is about $60 \mathrm{~km}$ away from Ajman city to the eastward. Most of the main Emirate's landmass is developed, with extensive suburbs stretching out almost to the E311 arterial road, with light industrial zones and warehousing towards the northeast. The small areas of sandy desert outside the city support scant seasonal growths of wild grasses and scrub, ghaf trees and occasional date palms.

\section{Data and methodology}

\subsection{Wind speed data location}

Figure 1 shows the overview of the city of the Emirate of Ajman. The Offshore point P1 (Lat 25.4354, Long 55.4027) and the Onshore point P2 (Lat 25.4005, Long 55.5316) on the Figure shows the study location where global reanalysis wind data and NASA satellite measured raw wind data has been obtained for this study.
Knowing the uncertainty and how much is the variation in site specific wind characteristics both vertically and horizontally is a must to assess the wind resources, install and successfully operate wind energy devices in any areas. In order to assess the site-specific wind energy resources, there must be long-term measured site-specific wind and climate data. In the absence of long term measured wind and climate data at the hub height of a wind turbine, literature shows that satellite or reanalysis winds are used for wind resource assessments, and this data has been considered reliable for wind resource assessments for both the offshore and onshore regions around the world. The studies such as [6-8,11-13], etc., have all used reanalysis wind for their studies on wind resource assessments. Among all the literature, ERA 5 is the most used mesoscale predicted reanalysis data for wind resource assessments $[12,13]$. To date, there is no validated mesoscale or satellite measured wind data available for the Emirate of Ajman. Based on the above literature as a preliminary investigation to make a prefeasibility overview of the variations in wind speed between two different data sources in the Emirate of Ajman, wind speed data sets from NASA satellite measured Power Data has been compared with ERA-5 global reanalysis data set. The data has been obtained for an Offshore and Onshore Point. The result of this analysis would be used as an input for further decision making for a comprehensive WRA. The following section details more about these data sources.

\subsection{ECMWF reanalysis v5 (ERA5)}

ERA5 is the fifth generation atmospheric reanalysis data from the European Center for Medium-Range Weather Forecasting. ERA5 uses the Integrated Forecasting Systems and includes atmospheric, land surface and ocean wave models. ERA5 has a high spatial and temporal resolution. The horizontal resolution is approximately $31 \mathrm{~km}$ and has 137 vertical levels (https://www.ecmwf.int/en/fore casts/datasets/reanalysis-datasets/era5). For this present study, wind data from1st Jan 2019 to 31 December 2019 at 
10-metre height has been used for an offshore and onshore point in the Emirate of Ajman (see Fig. 1).

\subsection{NASA satellite power data}

Through its Earth Science research program, NASA has long supported satellite systems and research providing data important to the study of climate and climate processes. The wind speed data from the NASA power source is taken from MERRA-2 and represents estimates at $2 \mathrm{~m}, 10 \mathrm{~m}$, and $50 \mathrm{~m}$ above the local surface over a $0.5 \times 0.5^{\circ}$ global grid; https://power.larc.nasa.gov/). These satellite and model-based products have been shown to be accurate enough to provide reliable solar and meteorological resource data over regions where surface measurements are sparse or nonexistent. For this present study, NASA power wind data from 1 January 2019 to 31 December 2019 (at 10-metre height) has been used for an offshore and onshore point in the Emirate of Ajman (see Fig. 1).

\section{Major studies on wind resource assessments in MENA region}

For several decades, researchers in different parts of the world have carried out Wind energy studies. In the year 2013, reference [14] analysed the efforts taken by Gulf GCC nations, and they discussed why the GCC nations must take action towards researching and implementing renewable energy resources. The study recommended that the government fund the research and development projects and the development organisations should work and support the Renewable energy resource and technology development [15]. Performed a spatial and temporal wind data analysis to find the areas having the highest wind energy potential at offshore regions of Oman. They used Weibull statistical function to analyse the wind data. They found that, in Oman, deploying offshore wind energy turbines can produce 1.34 times more wind energy than onshore. They used ECMWRF ERA5 Reanalysis mesoscale wind data for this assessment without any sitespecific extensive validation and verification of this model predicted data. Hence the study cannot be considered as a bankable WRA study. Since the government of Oman is targeting a $30 \%$ renewable energy growth by 2030 , the study recommended that, there should be further extensive wind resources assessment studies using more reliable offshore wind data sets.

A study by [16] in Iran concluded that Tehran's wind potential was not suitable for large-scale wind power production. They used 11 years of wind data collected at the height of 10 metres from two locations. They found that the data was matching for a mean yearly Weibull scale parametre of 2.02 and a mean yearly Weibull shape parametre of 4.81. The highest wind potential observed was in April. The lowest was in August. They concluded that the wind potential at the site is suitable only for local consumptions like charging of the battery and pump water. Khonkar [17] studied the behaviour of offshore wind over the Arabian Gulf using 47 years of mesoscale wind data sets from the International Comprehensive Ocean-Atmosphere (ICOADS) model. This data set is low-resolution data compared to other mesoscale data sets like ERA 5. Weibull distribution statistical function has been used [17] to understand the wind speed distribution over the Arabian Gulf. The study showed a $25 \%$ improvement in wind speed over the Arabian Gulf for the months like November, December, January and February, indicating the influence of Shamal winds. The wind speed was increased to $7.77 \mathrm{~m} / \mathrm{s}$. The study recommended that more data collection on onshore and offshore locations on an hourly basis is required. Even though they used low-resolution data, there was a clear indication that there is a clear influence of Shamal winds on the Arabian Gulf's wind patterns.

The wind resources in the Emirate of Ras Al Khaimah (RAK-UAE) was assessed by [18] using three years (20102012) weather data. They found that wind resources in RAK cannot be used for wind energy production. They have also, used only three years of weather data from a station installed in the industrial area at 10 metres. Considering the large area of the RAK emirate, the data is not sufficient to be used for decision making WRA. Moreover, the wind speed can vary significantly in long years as the wind speed in the region is influenced by the Indian Ocean. The wind energy potential of the whole Arabian Gulf was studied by [19]. The study assessed the wind energy potential at $10 \mathrm{~m}, 30 \mathrm{~m}$ and $50 \mathrm{~m}$ heights from the sea surface. Weibull statistical function was fitted to the wind speed data. They found that the central part of the Arabian Gulf has a higher average wind speed ranging from 6 to $8 \mathrm{~m} / \mathrm{s}$ at $10 \mathrm{~m}$ elevation, 7 to $8 \mathrm{~m} / \mathrm{s}$ at $30 \mathrm{~m}$ elevation and 8 to $9 \mathrm{~m} / \mathrm{s}$ at $50 \mathrm{~m}$ elevations. Since this region lies in the Class 2 category of the Wind Energy Resource Atlas of the United States, they recommended developing a large scale wind power project at the central region of the Arabian Gulf at elevations of $30 \mathrm{~m}$ or $50 \mathrm{~m}$. Since the study is not considering the influence of global climate indices and extreme events in the region as it has got strong influence on the wind speed duration, the study needs to be appended with a comprehensive wind resource assessment using site-specific met-ocean parametres.

A feasibility study to design a floating offshore wind energy turbine in UAE was conducted [20]. The study analysed the economic feasibility and wind energy resource utilisation chances in the Arabian Gulf. The study concluded that there is a high chance of installing floating offshore wind farms the offshore of Abu Dhabi. A GIS study was conducted by [21] to check the feasibility of installing wind turbines offshore of Abu Dhabi, UAE. The study was conducted based on the site sensitivity criteria's and sensitive receptors present in the Abu Dhabi waters. The study showed that except around Delma Island and North of Jabal Barakah in the Western Region, all other areas are unsuitable due to various physical and biological constraints. The study concludes that further research is needed to identify the suitable wind energy device to be installed in the area by considering multiple physical and biological constraints in the Arabian Gulf. Further, the study analysed win data at 50 metres height over UAE obtained from renewable energy laboratory. The data showed that the Emirate of Abu Dhabi experiences a wind 
speed range of 5 to $6 \mathrm{~m} / \mathrm{s}$. As per [21], this wind speed range is enough to construct a wind farm offshore of Abu Dhabi.

A climatological wind study over the Arabian gulf by [22] showed that sea breeze occurs in all seasons of the year, starting from late afternoon until evening. A strong land breeze was noticed during the night due to the presence of hills. In addition, the study noticed that during the summer months, the Indian monsoon creates light north-westerly winds over the Arabian Gulf, allowing for the formation of thermally driven circulations. A comprehensive study of wind potential over Algerian territory was studied by [23] using ERA-Interim reanalysis data for 33 years (1981-2014). The data were validated against observational data using the two-sample Kolmogorov-Smirnov and the Wilcoxon-Mann-Whitney tests. The mean wind speed was in between $2.3 \mathrm{~m} / \mathrm{s}$ in the North and $5.3 \mathrm{~m} / \mathrm{s}$ in the South. They found that, throughout the country, the windiest periods were day time of the warmer months. Wind characteristics study over morocco by [24] using data sets from 11 stations showed a wind speed range from $5 \mathrm{~m} / \mathrm{s}$ to $10 \mathrm{~m} / \mathrm{s}$ with average power density ranging from $100 \mathrm{~W} / \mathrm{m}^{2}$ to $1000 \mathrm{~W} / \mathrm{m}^{2}$. They opined that this power might be suitable for installing wind turbines. They found that Morocco's Wind speed distribution data was better fitted with Weibull hybrid distribution in contrast to the Weibull distribution. Evaluation of wind power in Jordan by [25] using mean monthly wind speed data over a year were undertaken. They found that the wind distribution data well fit with the Weibull distribution. They found that in Jordan, eastern desert regions with wide plain lands are economically feasible to be used for wind farms. In Iraq, to develop renewable energy resources [26], studied the way to optimise wind energy production system for a low wind speed region with flat terrain through a comprehensive, iterative methodology by selecting, matching, laying out and installing the most suitable wind turbine system.

Selection of the best probability density function to describe the wind speed distribution reduces the error in wind power estimation. The study by [27] used various probability distributions on wind speed data from 9 stations. They found that the Kappa and Generalized Gamma distributions best fit wind speed data at all heights and stations. However, since the long-term wind speed distribution of UAE varies with season and can be influenced by global climatic indices, the study would have been given better results by considering other major climatic variables that affect the wind speed distributions at the location.

Reference [28] first showed that the Weibull distribution is the best fit in displaying the data obtained during field experiments and wind speed measurements. Work by $[29,30]$ found that wind speed in the summer was associated with North Atlantic Oscillation, East Atlantic Oscillation, and the wind speed in winter and autumn was influenced by El Niño Southern Oscillation and the Indian Ocean Dipole indices. In Kuwait, [31] studied wind power densities of eight offshore stations from January 2012 to December 2015. They had estimated the parameters of Weibull distributions. Using the wind speed data, they analysed an offshore wind turbine with $50 \mathrm{MW}$ capacity and compared it with an $800 \mathrm{MW}$ thermal power plant. They found that power production from the offshore wind turbine was about $30 \%$ cheaper compared to the oil-based thermal power plant.

In 2009 [32], studied the flow on a downwind, twobladed, horizontal-axis wind turbine to investigate the flow lift, drag and wake characteristics on the tower blade interaction for implementing it in the low wind speed region $(3$ to $5 \mathrm{~m} / \mathrm{s})$. The study utilising the WAsP model and Arc GIS program was used to produce the map of the wind energy distribution for 6 locations in Iraq by [33]. They used this method to identify the best location for wind energy utilisation. Reference [34] used sample wind speed data for applying three methods for calculating the Weibull parameters and identifying the most accurate method. They found out that the maximum likelihood method is the most suitable to be used for analysing timeseries data and further concluded that the modified Weibull maximum likelihood method is recommended for use with wind data in frequency distribution format. The latest study by [35] concludes that, due to the tremendous decreases in the cost of wind turbines, by 2050 , the world would be achieving a 100\% clean energy production target by providing a huge amount of job opportunities and reducing the caron emission by more than 3.3 billions per year. Furthermore, the study point outs that, Offshore floating wind turbine will dominate the future wind energy technology market.

\section{Environmental characteristics of the Emirate of Ajman}

This section discusses the main environmental characteristics of the Emirate of Ajman which would influence the implementation of a major wind energy project.

\subsection{Terrain and roughness length variations over the Emirate of Ajman}

Figure 2 depicted and shows the terrain elevation details of the Emirate of Ajman. The terrain elevation varies from the east of the Emirate, where there is less construction and building developments. This variation in terrain would create a difference in wind pattern between the rural and urban areas of Ajman. Due to these changes in terrain elevation, there is variation in the roughness length over onshore areas of Ajman. Figure 3 shows the changes in the roughness length over the Emirate. As shown in Figure 3, the higher roughness length in Ajman cities would slow down the wind as the building would cause sheltering effects and affect wind speed characteristics. Since the wind speed greatly influences the landscape change, site-specific wind resource assessment is mandatory by considering the variations in physical terrain characteristics over the Emirate. Analysis of the terrain data indicates that the eastern part of the Emirate on the onshore side and the Hajar Mountains at Masfout and Manama may be suitable for installing smaller individual wind turbines or wind farms. These hilly mountain areas of Ajman can have high wind resources due to the speeding of the wind over the mountains. 


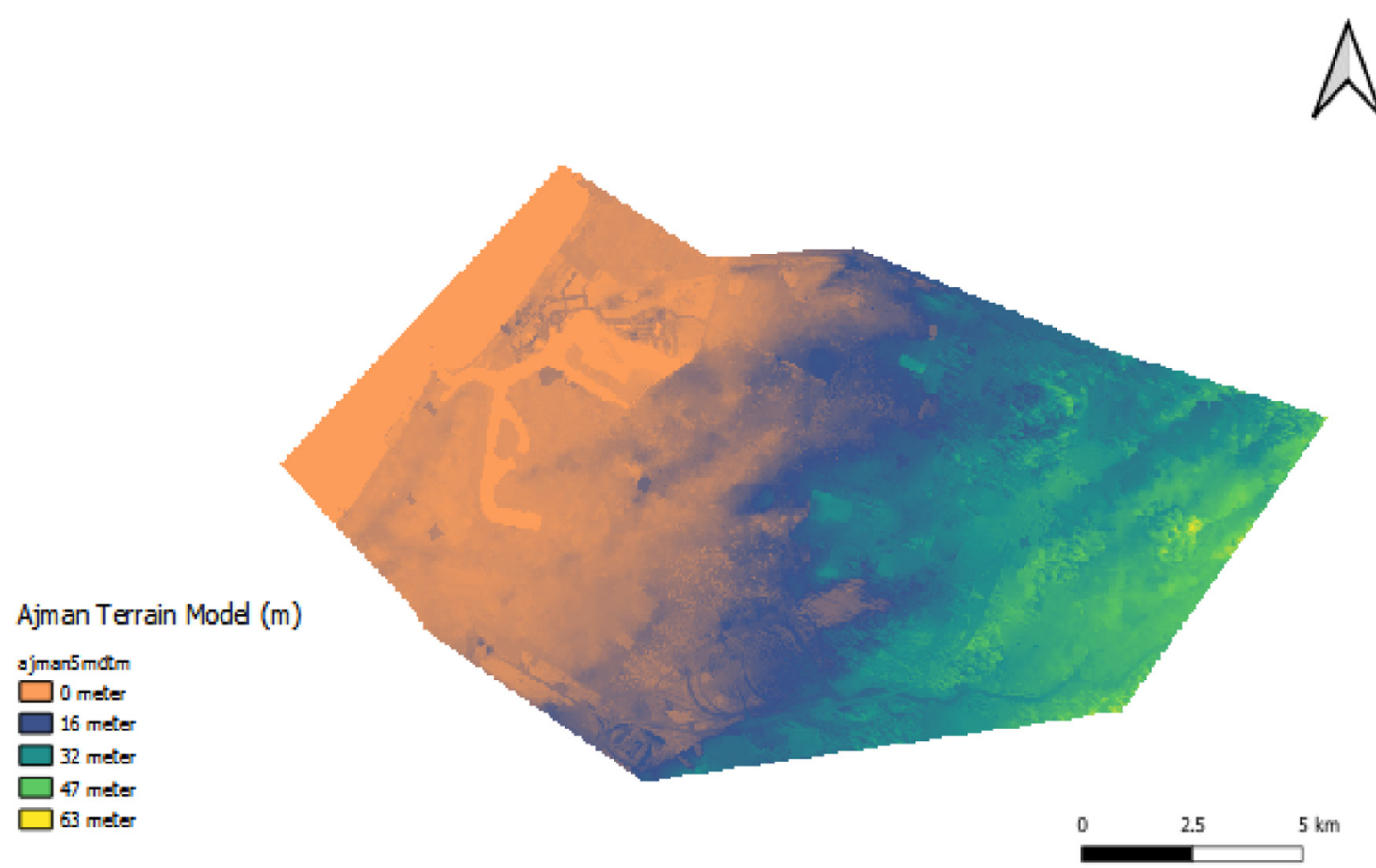

Fig. 2. Ajman Terrain Elevation Model (Source: Ajman Municipality \& Planning Department- Ajman-UAE).

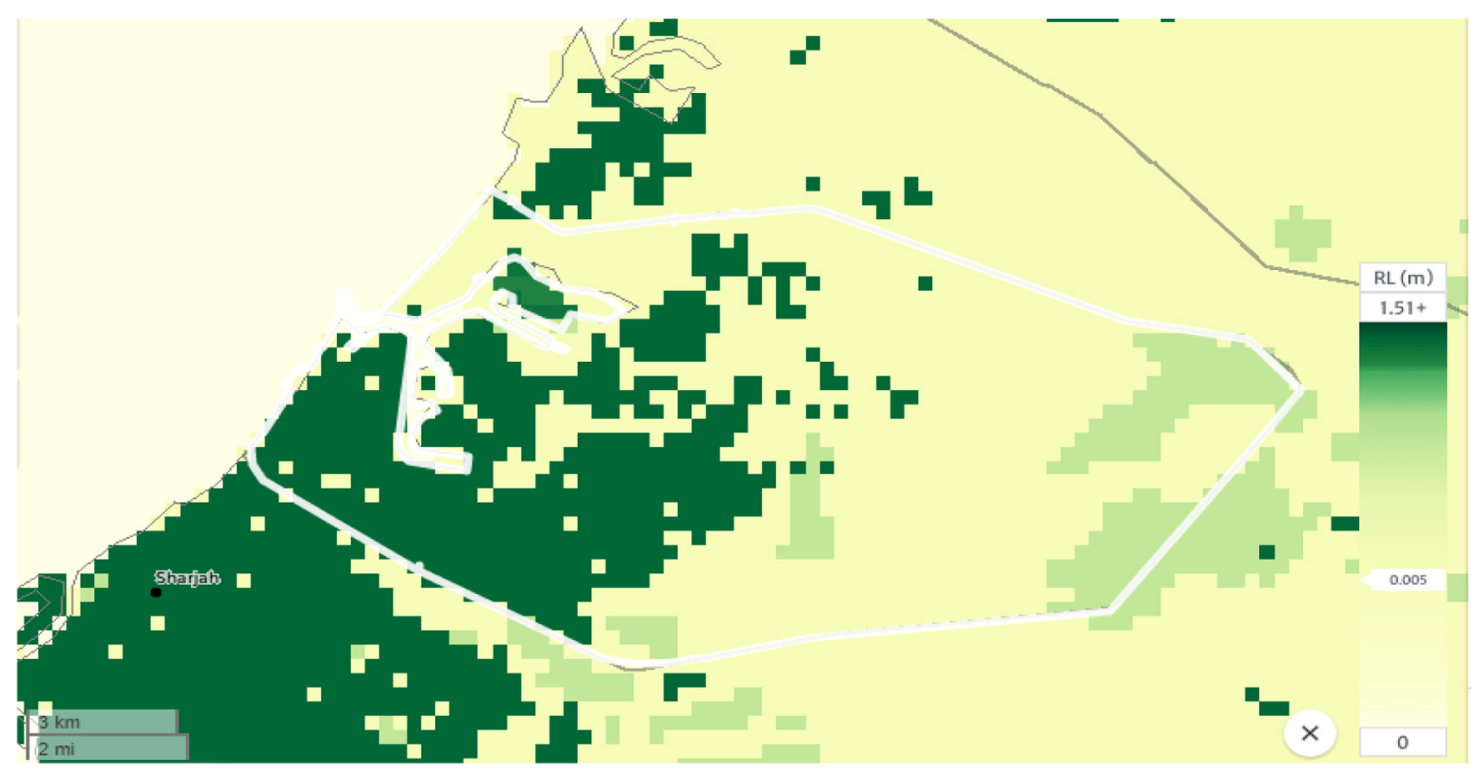

Fig. 3. Roughness length variations at the onshore areas of the Emirate of Ajman (Source: The Global Wind Atlas/the World Bank group).

On the other hand, the bottom roughness of the Emirate of Ajman would highly affect the wind speed over onshore places due to the changes in the internal boundary layer, which would mostly reach 100 metre from the surfaces due to the presence of various obstacles. Due to roughness, height and obstacles, wind speed over land changes and becomes less in the land than offshore. In effect, this variability of the vertical wind shear, the vertical profile of the average horizontal wind speed strongly depends on the bottom roughness. The bottom roughness strongly influences the wind velocity profile. This theoretical variation of the wind profile can be incorporated into the power-law exponent as a function of surface roughness and stability [36] using euro code as given 
Table 1. Surface friction lengths (Zo) and minimum friction heights (Zmin) (Adopted from Euro Code).

\begin{tabular}{llll}
\hline Terrain No & Terrain type & $Z_{\mathrm{o}}(\mathrm{m})$ & $z_{\min }(\mathrm{m})$ \\
\hline 0 & Coastal areas exposed to open sea & 0.003 & 1 \\
I & Lake shores and flat open areas with no obstacles & 0.01 & 1 \\
II & $\begin{array}{l}\text { Areas with low vegitaton and isolated obstacles where the average obstacle } \\
\text { separation is more than 20 times the average obstacle height. }\end{array}$ & 0.05 & 2 \\
& $\begin{array}{l}\text { Villages and suburbs, where the average obstacle separation is less than 20 } \\
\text { III }\end{array}$ & 0.3 & 5 \\
& $\begin{array}{l}\text { Cimes the average obstacle height. } \\
\text { IV }\end{array}$ & 1.0 & 10 \\
& with structures taller than $15 \mathrm{~m}$.
\end{tabular}

$Z_{0}$, surface friction length in metres. $Z_{\text {min }}$, minimum friction height in metres where the surface friction is constant.

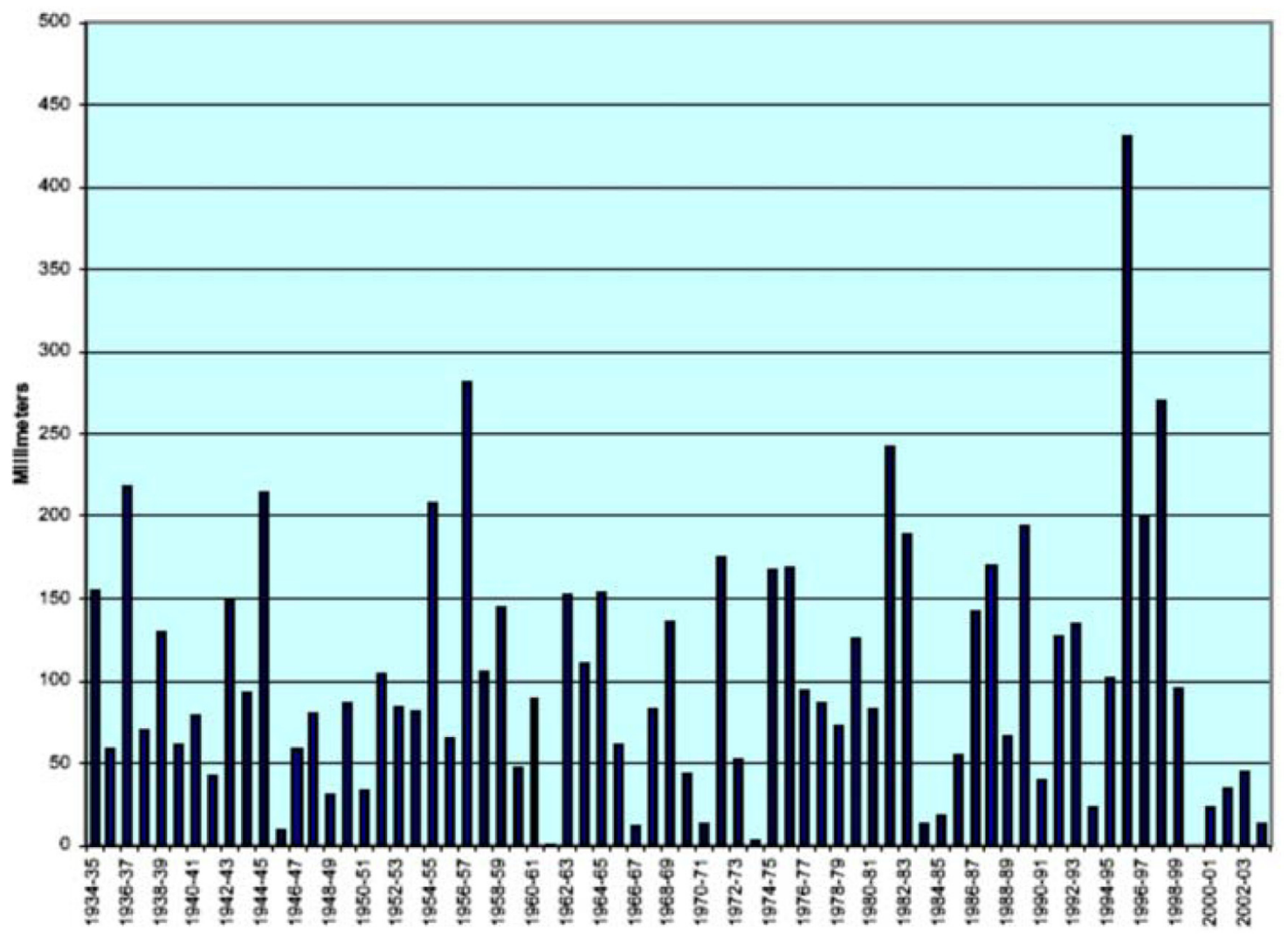

Fig. 4. Rainfall in Sharja - $10 \mathrm{~km}$ from the nearest coastline of Ajman (Feulner 2006).

in Table 1. So this indicates that it is mandatory to study the long term changes in site-specific wind characteristics at each of the potential locations over Ajman.

\subsection{General climatology of the Emirate of Ajman}

Generally, Ajman has a subtropical desert climate characterised by hot, dry conditions, with a hot summer and a warm winter. Humidity along the coast reaches above $70 \%$, and average precipitation is around $100 \mathrm{~mm}$ (with significant annual fluctuations), with basically all rainfall occurring during the winter months. Data on rainfall and temperature are taken from Sharjah Airport, some $10 \mathrm{~km}$ in a south-western direction from the Site (see Fig. 4). This would influence the climatology of Ajman, and it would vary between seasons. Hence, a comprehensive WRA in the Emirate of Ajman should consider the changes in wind speed during Fall Transition (OctoberNovember), during the Northeast Monsoon (DecemberMarch), during the Southwest Monsoon (June-September) and during the Spring Transition (April-May) seasons.

\subsection{Variations in wind speed at an offshore and onshore location in Ajman between two different Wind data sources}

The annual wind speed and its distribution at any location decide the annual energy output from a wind 


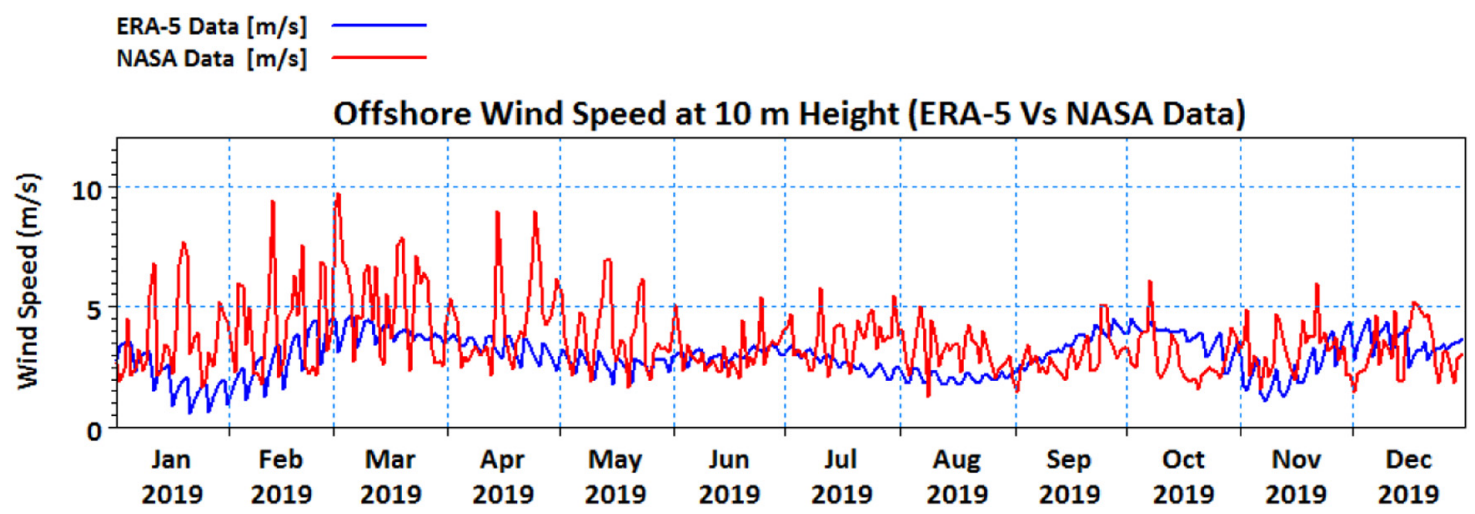

Fig. 5. Wind speed at offshore of Ajman at 10 metre height- ERA-5 Vs NASA satellite power data.

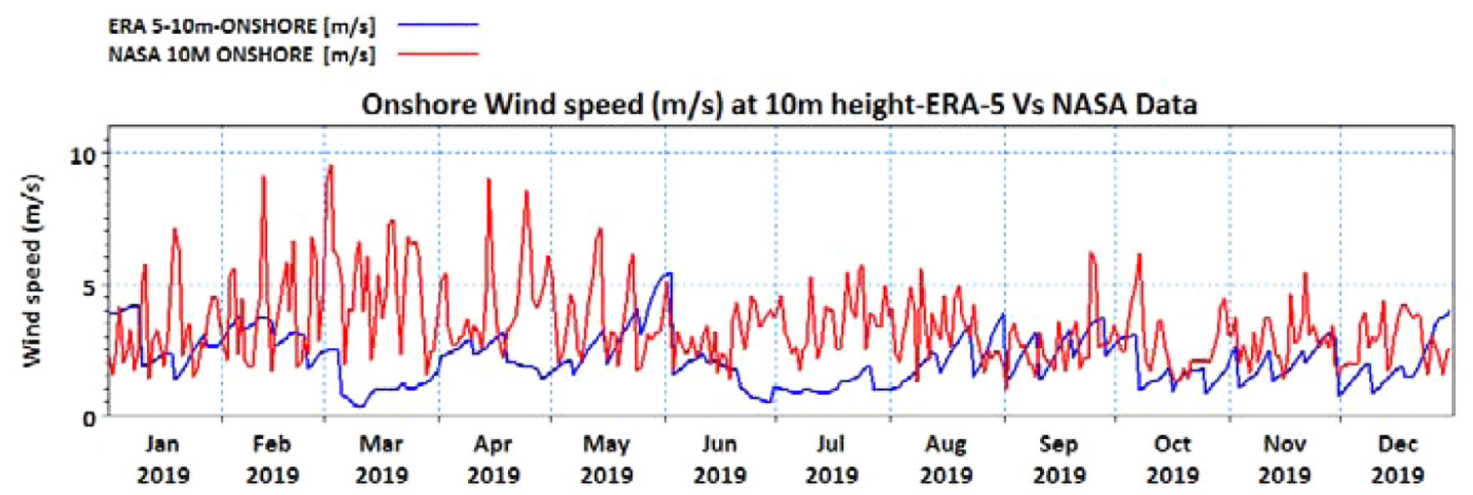

Fig. 6. Wind speed at onshore of Ajman at 10 metre height- ERA-5 Vs NASA satellite power data.

Table 2. Summary of raw data ECMWF reanalysis (ERA-5) raw data vs NASA satellite power raw data.

\begin{tabular}{llll}
\hline \multicolumn{1}{c}{ Data source } & & Minimum $(\mathrm{m} / \mathrm{s})$ & Maximum $(\mathrm{m} / \mathrm{s})$ \\
\hline \multirow{2}{*}{ ECMWF Reanalysis (ERA-5) data } & Offshore & 1 & 7.0 \\
& Onshore & 3.3 & 4.6 \\
\multirow{2}{*}{ NASA Satellite Power Data } & Offshore & 1.3 & 9.7 \\
& Onshore & 1.0 & 9.5 \\
\hline
\end{tabular}

turbine system. Hence, error-free, precise wind speed data has a great consequence. As we saw in Section 3.2, considerable researchers in the past used the fifth generation atmospheric reanalysis data sets and wind data sets measured by satellites for WRA. Since the above is the case, this study looks in detail at how the wind speed and its distribution varies between two such data sources in the case of the Emirate of Ajman to decide a way forward for a comprehensive WRA.

\subsection{ECMWF reanalysis (ERA-5) Vs NASA satellite power data}

Figure 5 shows the plot of monthly variation of wind speed for the year 2019 using ERA-5 reanalysis and NASA Satellite measured raw data at 10-metre height offshore of Ajman. At Offshore of Ajman ERA-5, reanalysis raw data shows a maximum value of $4.64 \mathrm{~m} / \mathrm{s}$, and NASA Satellite
Power Data Shows a maximum value of $9.74 \mathrm{~m} / \mathrm{s}$. Similarly as seen in Figure 6 at the Onshore point, ERA-5 reanalysis raw data shows a maximum value of $5.42 \mathrm{~m} / \mathrm{s}$, and NASA Satellite Power Data Shows a maximum value of $9.52 \mathrm{~m} / \mathrm{s}$. As seen in Figure 5, this fluctuation in wind speed may be attributed to the shift in seasons over the Emirate of Ajman (see Sect. 5.2). Table 2 shows the data summary for ECMWF Reanalysis (ERA-5) and NASA Satellite Power Raw Data, indicating a high variation for maximum wind speed value.

\subsection{Wind speed distribution at offshore and onshore of Ajman-ECMWF reanalysis (ERA-5) raw data vs NASA satellite power raw data}

Figures 7 and 8 shows wind speed distribution at Offshore and Onshore of Ajman. The graph explains how often the wind blows and its strength during the year 2019. Since 


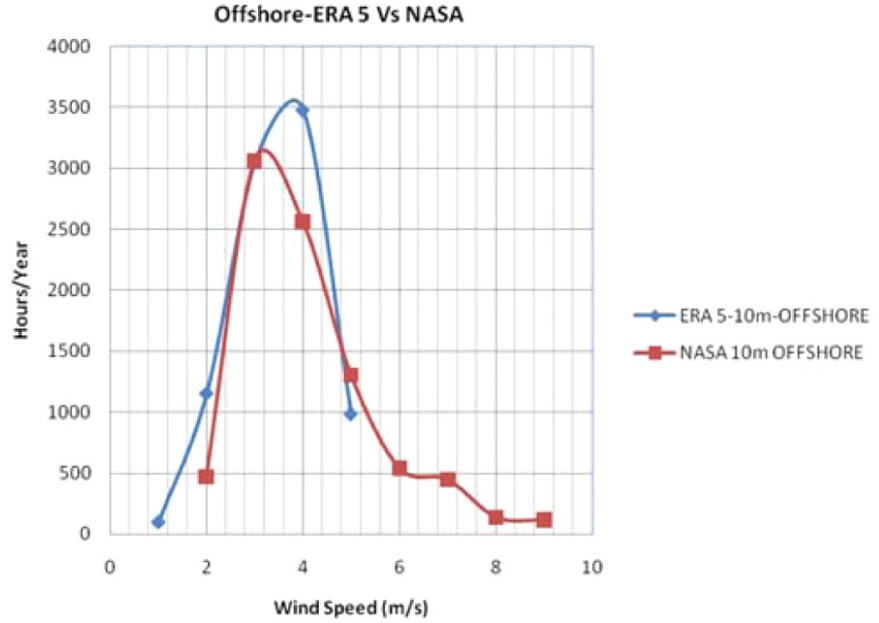

Fig. 7. Wind speed distribution at offshore at 10 metre heightERA-5 vs NASA satellite power data.

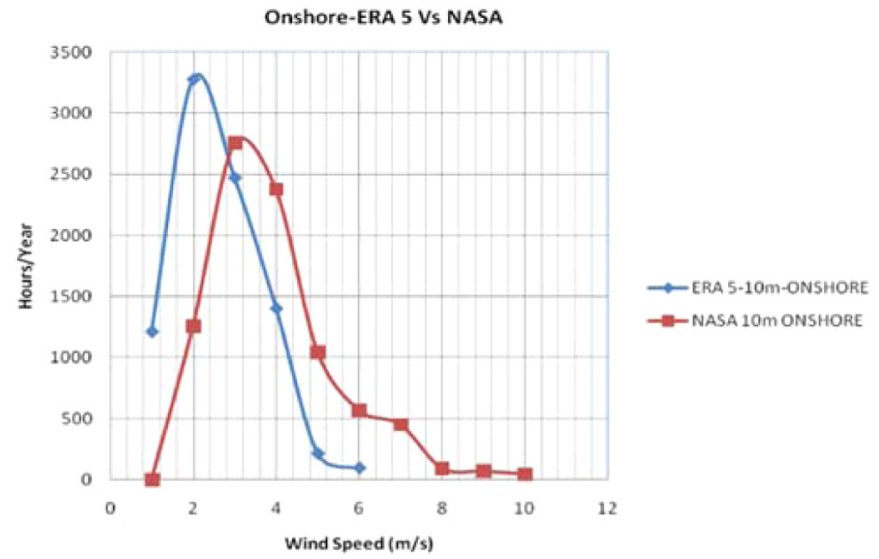

Fig. 8. Wind speed distribution at onshore at 10 metre height ERA-5 vs NASA satellite power data.

Wind Speed $(\mathrm{m} / \mathrm{s})$ at Offshore of Ajman (2019)

Data Source: ECMWF Reanalysis (ERA-5)

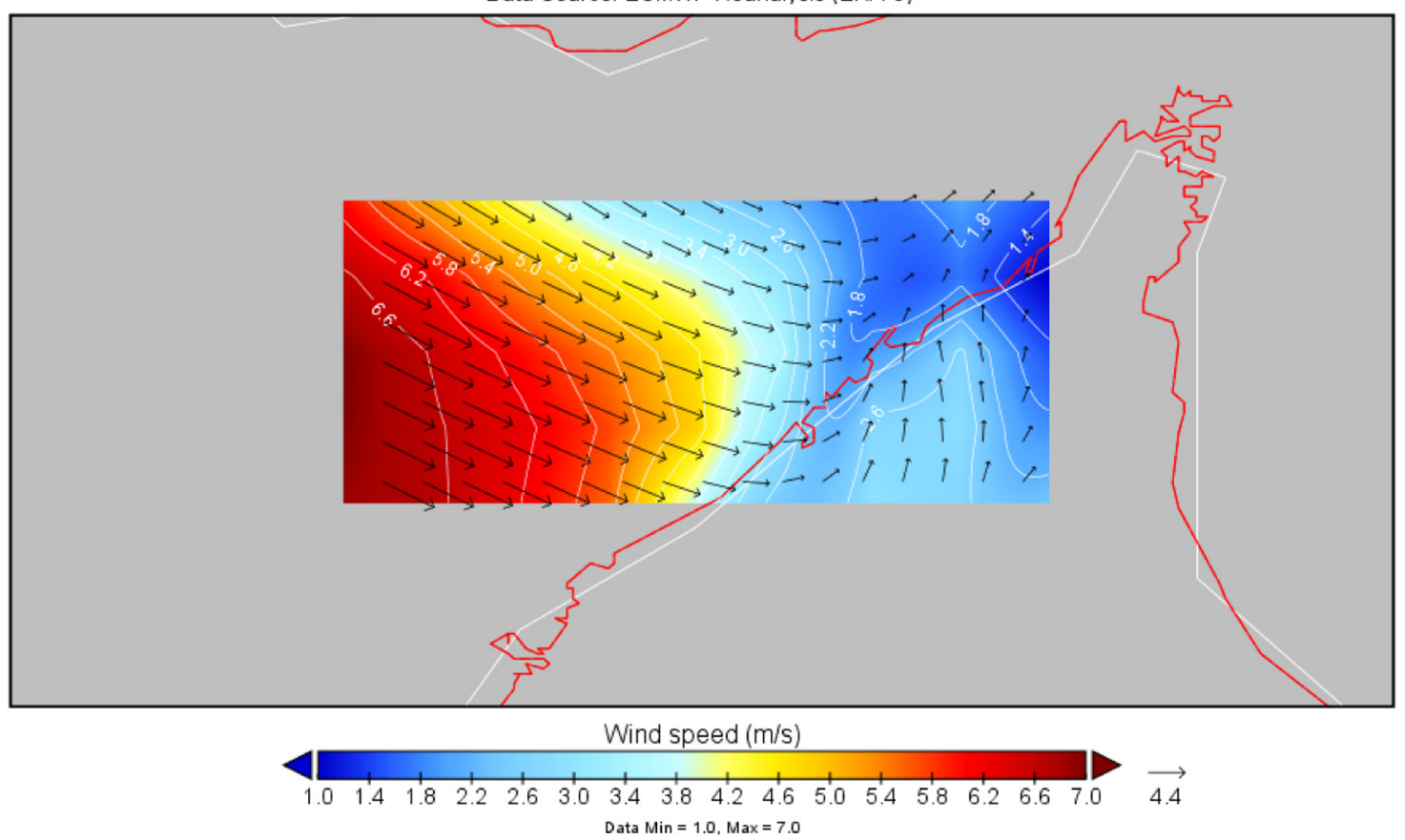

Fig. 9. Wind speed at offshore of Ajman at 10 metre height during 2019.

the information of wind speed distribution affects the annual energy production of the wind turbine, the exact error-corrected wind speed distribution data at the location is compulsory for bankable WRA. In addition to the wind speed distribution directly related to the wind, a turbine power curve would calculate the possible annual electrical energy production for a specific wind turbine for a sitespecific location. Mathematically most of the time, wind speed distribution data and the curve follow a basic hypothesis, which shows that wind speed data at a location is distributed and approximated using a Weibull distribution [36]. However, the curves in the graphs below show that the red colour wind distribution curve using NASA satellite power data is significantly skewed. Hence, this wind speed distribution data cannot be explained using a single parameter Weibull distribution. Since this study is a comparative study to show the importance of a comprehensive WRA over the Emirate of Ajman, further in-depth research using error-corrected long term measured wind data in conjunction with a selected long term mesoscale wind and weather data should be planned to support a sitespecific bankable WRA.

Figures 9 and 10 shows ho wind speed offshore and onshore of Ajman varies at 10-metre height during the year 2019 as per ECMWF Reanalysis (ERA-5) data. The figures clearly show that there is a good wind potential at Offshore 
Wind speed $(\mathrm{m} / \mathrm{s})$ at Onshore of Ajman (2019)

Data Source ECMWF Reanalysis (ERA-5)

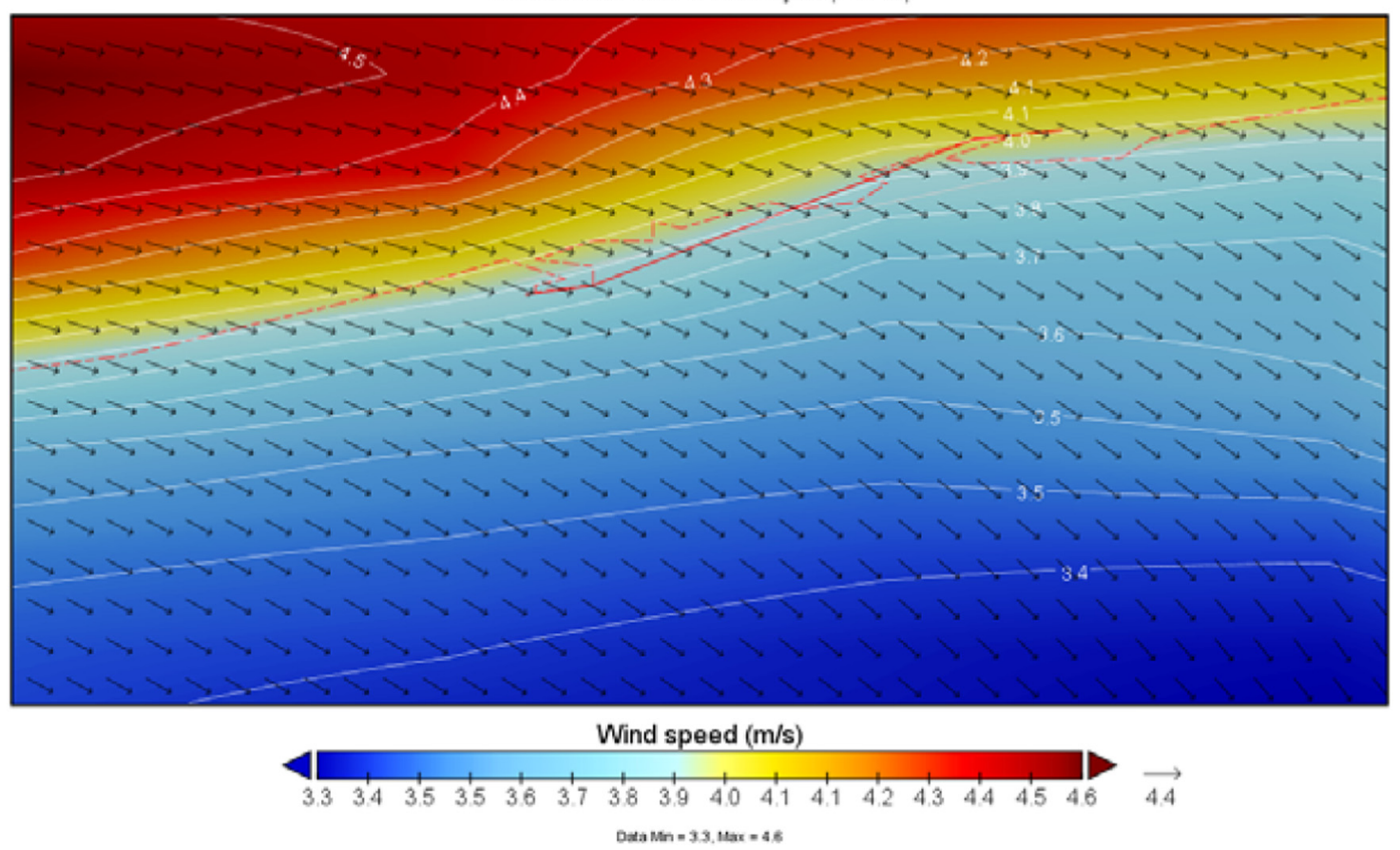

Fig. 10. Wind speed at onshore of Ajman at 10 metre height during 2019.

of Ajman compared to Onshore. The study must be extended to understand the site-specific wind potential at all the potential identified sites by considering all the physical constraints for a wind farm development.

Westerly and north-westerly winds dominate the wind on the Offshore of Ajman throughout the year (see Figs. 9 and 10). Wind speeds are most frequently within the range of $1-10 \mathrm{~m} / \mathrm{s}$ between two data sources. This can include wind speed during normal and during extreme events. Since extreme events at first 100 metres of the atmosphere would affect the wind turbine operations, this must be further studied over the Emirate of Ajman.

\subsection{Conclusion and way forward for the Emirate of Ajman}

Over the years, many studies have been conducted worldwide to study offshore wind characteristics for developing wind farms to generate sustainable electricity. Humans need for energy has been increasing. This requirement can be met only by using sustainable energy resources like wind energy. Due to the sun earth relationship, horizontal air pressure differences result in the generation of sustainable wind energy. In the past, to site a wind turbine and a wind farm, information on frequency distribution and mean wind speed at hub height was only used. Still, due to the increase in size and height of installation and high altitude wind energy devices $(80 \mathrm{~m}$, $150 \mathrm{~m}, 500$ metre etc., with power up to $9 \mathrm{MW}$ ), the situation has been changed. It became mandatory to incorporate wind shear profile and all the related climate variables and information about extreme events that need to be known to avoid underestimating total power from the wind energy systems. It is even economically and practically hard to install the measuring masts in these high heights. Installing and operating wind energy devices where the long term changes and details of the atmosphere's vertical structure are not known would cause high economic loss.

This study finds that regional wind resource assessment studies carried out over Arabian Gulf using mesoscale model predicted data sets. The review indicates that wind resources in the Arabian gulf vary seasonally with years due to the influence of global climatic indices and extreme events in the region. As this study suggests (see Figs. 5 through 8), the mesoscale data sets from two different sources give different results for a single specific location and region.

As depicted in Figure 7, the analysis of ERA-5 Data at 10-meter height at the Offshore location for the year 2019 shows that wind speed with $4 \mathrm{~m} / \mathrm{s}$ occurs for 3500 hours/ year. Still, for the same location, the data obtained from the NASA satellite for the same period shows that the wind speed with $4 \mathrm{~m} / \mathrm{s}$ had blown only for 2500 hours/year. Similarly, as seen in Figure 8, for onshore location, at 10-meter height the ERA-5 data shows wind speed with magnitude $4 \mathrm{~m} / \mathrm{s}$ has a duration of 1400 Hours/year, whereas NASA satellite Data shows that $4 \mathrm{~m} / \mathrm{s}$ wind speed has a duration of 2400 hours/year.

The above results show that wind speed distribution at a particular location keeps varying with the source of wind data. Hence wind resource assessment only by using a 
mesoscale model data or satellite measured data cannot be considered for a bankable wind resource assessment in the Emirate of Ajman. The wind resources vary seasonally along with other parameters and global climatic indices. Therefore as a way forward, a site-specific error correction technique must be developed using measured climate variables (air temperature, atmosphere pressure, solar radiation, relative humidity and rainfall) and wind data at maximum locations over Ajman in conjunction with an easily and publicly available mesoscale or satellite measured wind data.

The critical review of previous methodologies adopted on wind resources assessments shows that no studies used a particular offshore wind resource assessment method. It is risky to use the same onshore principles and methodologies for the offshore by considering all dependent parameters of wind speed. As explained by [37], offshore meteorology is different from onshore as the offshore wind turbines operate on the Ekman layer of the marine atmospheric boundary layer (MABL). Hence, site-specific long-term data sets from different sources and other related climate variables are mandatory for the economic, logical evaluation of the spatial and temporal distribution of wind energy and assessment of the wind resources at the selected onshore and offshore locations of the Emirate Ajman. This would facilitate the identification of potential resource sites for implementing wind energy systems. Hence it is mandatory to develop, understand and predict site-specific wind speed to enable the investors to know when to power upwind turbines [38].

In addition to the above, more research is needed to quantify the profiles of Shamal winds and extreme events in the Emirate of Ajman to be incorporated further into the wind energy sustainability studies. This would help the swift development of a sustainable wind energy system in the Emirate of Ajman. In this context, the current study was undertaken to initiate such an endeavour and plan further research on this topic. This would fill the gap of non-availability of site-specific, reliable and validated wind data for sustainable wind energy projects in the Emirate of Ajman.

\section{References}

1. Regional and Sustainable Development Department, Guidelines for Wind Resource Assessment: Best Practices for Countries Initiating Wind Development (2014) Available: https://www.adb.org/sites/default/files/publication/42032/ guidelines-wind-resource-assessment.pdf

2. K. Mueen Alhosani, Y. Omar Kaied, A. Salam Kareem Darwish, Ajman an environmentally friendly city with its quality of life: review of sustainability challenges and achievements by Ajman Municipality and Planning Department, Renew. Energy Environ. Sustain. 6, 12 (2021)

3. A. Sayigh, Up-date: Renewable energy and climate change, Renew. Energy Environ. Sustain. 6, 13 (2021)

4. A.S.K. Darwish, Wind energy utilisation for water desalination, street and buildings lighting - a case study for The
Emirate of Ajman - UAE, Renew. Energy Environ. Sustain. 6, $10(2021)$

5. S. Saha, S. Moorthi, H.-L. Pan, X. Wu, J. Wang, S. Nadiga, P. Tripp, R. Kistler, J. Woollen, D. Behringer, H. Liu, D. Stokes, R. Grumbine, G. Gayno, J. Wang, Y.-T. Hou, H.-y. Chuang, H.-M.H. Juang, J. Sela, M. Iredell, R. Treadon, D. Kleist, P. Van Delst, D. Keyser, J. Derber, M. Ek, J. Meng, H. Wei, R. Yang, S. Lord, H. van den Dool, A. Kumar, W. Wang, C. Long, M. Chelliah, Y. Xue, B. Huang, J.-K. Schemm, W. Ebisuzaki, R. Lin, P. Xie, M. Chen, S. Zhou, W. Higgins, C.-Z. Zou, Q. Liu, Y. Chen, Y. Han, L. Cucurull, R.W. Reynolds, G. Rutledge, M. Goldberg, The NCEP climate forecast system reanalysis, Bull. Am. Meteorol. Soc. 91, 1015-1057 (2010)

6. S. Saha, S. Moorthi, X. Wu, J. Wang, S. Nadiga, P. Tripp, D. Behringer, Y.-T. Hou, H.-Y. Chuang, M. Iredell, M. Ek, J. Meng, R. Yang, M. Peña Mendez, H. van den Dool, Q. Zhang, W. Wang, M. Chen, E. Becker, The NCEP climate forecast system version 2, J. Clim. 27, 2185-2208 (2014)

7. R. Gelaro, W. McCarty, M.J. Suárez, R. Todling, A. Molod, L. Takacs, C.A. Randles, A. Darmenov, M.G. Bosilovich, R. Reichle, K. Wargan, L. Coy, R. Cullather, C. Draper, S. Akella, V. Buchard, A. Conaty, A.M. da Silva, W. Gu, G.-K. Kim, R. Koster, R. Lucchesi, D. Merkova, J. Eric Nielsen, G. Partyka, S. Pawson, W. Putman, M. Rienecker, S.D. Schubert, M. Sienkiewicz, B. Zhao, The modern-era retrospective analysis for research and applications, version 2 (MERRA-2), J. Clim. 30, 5419-5454 (2017)

8. S.M. Uppala et al., J. R. Meteorol. Soc. 131, 2961-3012 (2005)

9. P. Berrisford, D.P. Dee, M. Fielding, M. Fuentes, P.W. Kållberg, S. Kobayashi, S. Uppala, ERA report series - The ERA-Interim archive Version 1.0, weather, p. 16, 2009. Available: http://www.ecmwf.int/publications/library/ecpu blications/_pdf/era/era_report_series/RS_1.pdf

10. H. Hersbach, B. Bell, P. Berrisford, S. Hirahara, A. Horányi, J. Muñoz-Sabater, J. Nicolas, C. Peubey, R. Radu, D. Schepers, A. Simmons, C. Soci, S. Abdalla, X. Abellan, G. Balsamo, P. Bechtold, G. Biavati, J. Bidlot, M. Bonavita, G. De Chiara, P. Dahlgren, D. Dee, M. Diamantakis, R. Dragani, J. Flemming, R. Forbes, M. Fuentes, A. Geer, L. Haimberger, S. Healy, R.J. Hogan, E. Hólm, M. Janisková, S. Keeley, P. Laloyaux, P. Lopez, C. Lupu, G. Radnoti, P. de Rosnay, I. Rozum, F. Vamborg, S. Villaume, J.-N. Thépaut, The ERA5 global reanalysis, Q. J. R. Meteorol. Soc. 146, 1999-2049 (2020)

11. V.S. Kumar, A.B. Asok, J. George, M.M. Amrutha, Regional study of changes in wind power in the indian shelf seas over the last 40 years, Energies 13 (2020) DOI: 10.3390/en13092295

12. S. Kucukali, Wind energy resource assessment of Izmit in the West Black Sea Coastal Region of Turkey 30, 790-795 (2014)

13. Q. Guo, X. Xu, K. Zhang, Z. Li, W. Huang, L.R. Mansaray, W. Liu, X. Wang, J. Gao, J. Huang, Assessing global ocean wind energy resources using multiple satellite data, Remote Sens. 10, 1-13 (2018)

14. R. Ferroukhi, N. Ghazal-Aswad, S. Androulaki, D. Hawila, T. Mezher, Renewable energy in the GCC: Status and challenges, Int. J. Energy Sect. Manag. 7, 84-112 (2013)

15. A. Al-hinai, Y. Charabi, S.H.A. Kaboli, Offshore wind energy resource assessment across the territory of oman: a spatialtemporal data analysis (2021) 
16. A. Keyhani, M. Ghasemi-Varnamkhasti, M. Khanali, R. Abbaszadeh, An assessment of wind energy potential as a power generation source in the capital of Iran, Tehran, Energy (2010) DOI: 10.1016/j.energy.2009.09.009

17. H. Khonkar, Complete survey of wind behavior over the Arabian Gulf, J. King Abdulaziz Univ. Mar. Sci. (2009) DOI: 10.4197/Mar.20-1.3

18. W. Kazim, O.B. Akash, Measurements and analysis of wind characteristics in northern emirates for wind power generation, Int. J. Appl. Eng. Res. 11, 11165-11170 (2016)

19. K. Al-Salem, S. Neelamani, W. Al-Nassar, Wind energy map of Arabian Gulf, Nat. Resour. 09, 212-228 (2018)

20. A.A. Al Qubaisi, S.S. Dol, M.S. Khan, A.A. Azeez, Feasibility study and design of floating offshore wind turbine farm in United Arab Emirates (2018) DOI: 10.1109/ ICASET.2018.8376800

21. N. Saleous, S. Issa, J. Al Mazrouei, GIS-based wind farm site selection model offshore Abu Dhabi Emirate, UAE, ISPRS Int. Arch. Photogramm. Remote Sens. Spat. Inf. Sci. (2016) DOI: $10.5194 /$ isprs-archives-xli-b8-437-2016

22. R.E. Eager, S. Raman, A. Wootten, D.L. Westphal, J.S. Reid, A. Al Mandoos, A climatological study of the sea and land breezes in the Arabian Gulf region, J. Geophys. Res. Atmos. 113, 1-12 (2008)

23. S.M. Boudia, J.A. Santos, Assessment of large-scale wind resource features in Algeria, Energy 189 (2019) DOI: 10.1016/j.energy.2019.116299

24. H. Nfaoui, J. Buret, A.A.M. Sayigh, Wind characteristics and wind energy potential in Morocco, Sol. Energy 63, 51-60 (1998)

25. H.D. Ammari, S.S. Al-Rwashdeh, M.I. Al-Najideen, Evaluation of wind energy potential and electricity generation at five locations in Jordan, Sustain. Cities Soc. 15, 135-143 (2015)

26. A.S. Darwish, S. Shaaban, E. Marsillac, N.M. Mahmood, A methodology for improving wind energy production in low wind speed regions, with a case study application in Iraq, Comput. Ind. Eng. 127, 89-102 (2019)

27. T.B.M.J. Ouarda et al., Probability distributions of wind speed in the UAE, Energy Convers. Manag. (2015) DOI: 10.1016/j.enconman.2015.01.036
28. A.S.K. Darwish, A.A.M. Sayigh, Erratum: Expression of concern (Wind energy potential in Iraq (1988) 27(1-3) (179-189), (0167610588900347)), J. Wind Eng. Ind. Aerodyn. (2020) DOI: 10.1016/j.jweia.2020.104344

29. M.S. Naizghi, T.B.M.J. Ouarda, Teleconnections and analysis of long-term wind speed variability in the UAE, Int. J. Climatol. 37, 230-248 (2017)

30. M.S. Naizghi, T.B.M.J. Ouarda, Teleconnections and analysis of long-term wind speed variability in the UAE, Int. J. Climatol. (2017) DOI: 10.1002/joc.4700

31. W.K. Al-Nassar, S. Neelamani, K.A. Al-Salem, H.A. Al-Dashti, Feasibility of offshore wind energy as an alternative source for the state of Kuwait, Energy 169, 783-796 (2019)

32. I. Janajreh, R. Qudaih, I. Talab, Z. Al Nahari, Atmospheric wind data collection and wind turbine analysis in UAE (2009) DOI: $10.1115 /$ ES2009-90288

33. S.M. Ali, A.H. Shaban, A.K. Resen, Integrating WAsP and GIS tools for establishing best positions for wind turbines in South Iraq, Int. J. Comput. Inf. Technol. 03, 2279-764 (2014)

34. J.V. Seguro, T.W. Lambert, Modern estimation of the parametres of the Weibull wind speed distribution for wind energy analysis, J. Wind Eng. Ind. Aerodyn. (2000) DOI: 10.1016/S0167-6105(99)00122-1

35. A.S. Darwish, R. Al-Dabbagh, Wind energy state of the art: present and future technology advancements, Renew. Energy Environ. Sustain. 5, 7 (2020)

36. D.P. Deea, S.M. Uppalaa, A.J. Simmonsa, P. Berrisforda, P. Polia, S. Kobayashib, U. Andraec, M.A. Balmasedaa, G. Balsamoa, P. Bauera, P. Bechtolda, A.C.M. Beljaarsa, L. van de Bergd, J. Bidlota, N. Bormanna, C. Delsola, R. Dragania, M. Fuentesa, A.J. Geera, L. Haimbergere, S.B. Healya, H. Hersbacha, E.V. Holḿ a, L. Isaksena, P. Kallberg, M. Kohler, M. Matricardia, A.P. McNallya, B.M. Monge-Sanzf, J.-J. Morcrettea, B.-K. Parkg, C. Peubeya, P. de Rosnaya, C. Tavolatoe, J.-N. Thepaut, F. Vitart, The ERA-Interim reanalysis: ConFigureuration and performance of the data assimilation system, Q. J. R. Meteorol. Soc. 137, 553-597 (2011) 37. S. Emeis, Wind Energy Meteorology (2013)

38. U. Aswathanarayana, Wind power, in Green Energy: Technology, Economics and Policy (2010)

Cite this article as: Kais Muhammed Fasel, Abdul Salam K. Darwish, Peter Farrell, Hussein Kazem, An Overview of Wind Resource Assessments With Special Reference to The Emirate of Ajman, UAE, Renew. Energy Environ. Sustain. 6, 32 (2021) 